\title{
PERBANDINGAN STABILITAS TANAH DENGAN \\ MENGGUNAKAN SEMEN PADA RUAS JALAN KABUPATEN \\ SORONG DAN RUAS JALAN DI KALIMANTAN
}

\author{
Nur Hidayah Annas ${ }^{1)}$ \\ 1) Program Studi Teknik Sipil Universitas Muhammadiyah Sorong \\ Jl. Pendidikan No 27 Kota Sorong \\ Email : nurhidayahannassipil@gmail.com
}

\begin{abstract}
Abstrak
Kabupaten Sorong adalah sebuah Kabupaten di provinsi Papua Barat, Indonesia. Ibu kota kabupaten ini terletak di Aimas. Kabupaten ini merupakan salah satu penghasil minyak utama di Indonesia. Kalimantan adalah sebuah pulau yang terletak di sebelah utara Pulau Jawa dan di sebelah barat Pulau Sulawesi. Terbagi menjadi wilayah Brunei, Indonesia dan Malaysia. Pembangunan jalan disetiap daerah selalu berbeda salah satunya adalah stabilitas tanah dari daerah masing-masing. Tujuan pembuatan artikel ini adalah untuk mengetahui perbandingan stabilitas tanah dengan menggunakan semen pada ruas jalan Kabupaten Sorong dan ruas jalan di Kalimantan. Pemakaian semen sebagai bahan adiktif banyak digunakan dalam beberapa penelitian di Indonesia terutama terkait dengan peningkatan kekuatan tanahnya. Dalam tulisan ini, pemakaian bahan stabilisasi semen diamati dari efek penggunaannya, seperti rentang kadar air tanah campuran, serta dari segi ekonomisnya. Stabilitas Tanah menggunakan semen tergantung pada jenis tanah apa yang akan digunakan atau yang akan dicampurkan dengan semen. Tanah gambut dikategorikan ke dalam tanah lunak yang sering digunakan bila harus dilalui oleh suatu trase jalan.
\end{abstract}

Kata Kunci : Stabilitas Tanah, Mengggunakan Semen, Sorong Kalimantan, 


\section{PENDAHULUAN}

Kabupaten Sorong adalah sebuah kabupaten di provinsi Papua Barat, Indonesia. Ibu kota kabupaten ini terletak di Aimas. Kabupaten ini merupakan salah satu penghasil minyak utama di Indonesia. Kawasan perairannya dikenal sebagai habitat penyu belimbing (Dermochelys coriacea vandelli). Kabupaten Sorong memiliki luas wilayah $18.170 \mathrm{Km} 2$, daerah ini berbatasan langsung dengan Kabupaten Raja Ampat di sebelah utara dan barat, Kabupaten Sorong Selatan di sebelah selatan, Kabupaten Manokwari disebelah timur, secara geografis terletak di 00o56 LS dan antara 131o07 BT.

Kalimantan adalah sebuah pulau yang terletak di sebelah utara Pulau Jawa dan di sebelah barat Pulau Sulawesi. Terbagi menjadi wilayah Brunei, Indonesia dan Malaysia. Dahulu nama pulau terbesar ketiga di dunia ini adalah Warunadwipa yang artinya Pulau Dewa Laut. Dalam bahasa Indonesia dahulu, Kalimantan Utara adalah sebutan untuk Borneo Utara (Sabah), tetapi dalam pengertian sekarang Kalimantan Utara adalah Kalimantan Timur bagian utara. Jadi dalam arti luas Kalimantan meliputi seluruh pulau Borneo, sedangkan dalam arti sempit Kalimantan hanya mengacu pada wilayah Indonesia. Pulau Kalimantan terletak di sebelah utara pulau Jawa, sebelah timur Selat Melaka, sebelah barat pulau Sulawesi dan sebelah selatan Filipina. Luas pulau Kalimantan adalah $743.330 \mathrm{~km}^{2}$. Pulau Kalimantan dikelilingi oleh Laut Cina Selatan di bagian barat dan utara-barat, Laut Sulu di utara-timur, Laut Sulawesi dan Selat Makassar di timur serta Laut Jawa dan Selat Karimata di bagian selatan.

Pembangunan jalan disetiap daerah selalu berbeda salah satunya adalah stabilitas tanah dari daerah masing-masing. Tujuan pembuatan artikel ini adalah untuk mengetahui perbandingan stabilitas tanah dengan menggunakan semen pada ruas jalan Kabupaten Sorong dan ruas jalan di Kalimantan. Stabilisasi tanah dengan semen diartikan sebagai pencampuran antara tanah yang telah dihancurkan, semen dan air, yang kemudian dipadatkan sehingga menghasilkan suatu material baru disebut Tanah-Semen dimana kekuatan, karakteristik deformasi, daya tahan terhadap air, cuaca dan sebagainya dapat disesuikan dengan kebutuhan untuk perkerasan jalan, pondasi bagunan dan jalan, aliran sungai dan lain-lain.

\section{METODE}

Lokasi Studi

Kabupaten Sorong dan Kalimantan

Tahapan Penyusunan Artikel :

1. Penentuan Tema Artikel

2. Penelusuran artikel yang bersesuaian dengan tema yang di ambil (memlui google scholar)

3. Analisa kompratif terhadap artikel yang didapatkan dari google scholar

4. Membuat kesimpulan untuk menjawab tujuan penulisan Artikel

Semua metode penulisan dan analisa dalam artikel ilmiah ini merujuk pada panduan penulisan tugas akhir Fakultas Teknik Universitas Muhammadiyah Sorong tahun 2014 (Pristianto, Amri, \& Rusdi, 2014). 


\section{HASIL DAN PEMBAHASAN}

\section{Penelitian dengan tema yang sama.}

Beberapa hasil penelitian terkait tema airtikel ini adalah sebegai berikut :

1. Menurut Pristianto (2018) yang meneliti tentang Uji Eksperimen Stabilisasi Tanah Dasar Dengan Semen Pada Ruas Jalan Malawili Distrik Aimas Kabupaten Sorong. Dengan kesimpulan antara lain :

1. Sifat-sifat indeks (index properties) menunjukkan sifat-sifat tanah yang megindikasikan jenis dan kondisi tanah, serta memberikan hubungan terhadap sifat-sifat mekanis seperti kekuatan dan pemampatan atau kecenderungan untuk memgembang, adapun sifat indeks tanah menunjukkan Berat Jenis Spesifik $(\mathrm{Gs})=36,88 \%$,Indeks Plastisitas (batas cair) $=17,49 \%$, Batas Susut $(\mathrm{SL})=43,11 \%$, dan Analisa Saringan lolos saringan no $200=3,44 \%$ dan yang tertahan $=96,56 \%$ dalam penelitian ini tanah yang digunakan jenis tanah lempung dimana tanah lempung merupakan agregat partikel-partikel berukuran mikroskopik dan submikroskopik yang berasal dari pembusukan kimiawi unsur-unsur penyusun batuan.

2. Hasil menunjukan bahwa dinilai $\mathrm{CBR}$, dan kepadatan standar naik dengan naiknya presentase semen didalam tanah. Pada kadar semen tersebut terlihat adanya penurunan potensi pengembangan dan peningkatan nilai CBR yang cukup signifikan. Pada pengujian tekan bebas terlihat bahwa semakin tinggi kadar semen, nilai parameter kuat geser tanah semakin naik. Penambahan semen telah mengingkatkan nilai daya dukung tanah secara singnifikan. Nilai CBR semakin naik jika seiring dengan penambahan semen, dimana nilai CBR tanah asli sebesar $1,62 \%$. Terjadinya peningkatan nilai CBR pada campuran optimum $7 \%$ semen dengan waktu pemeraman 3 hari dengan nilai CBR $3,76 \%$,

2. Meneliti tentang Studi Perilaku Kekuatan Tanah Gambut Kalimantan Yang Distabilisasi Dengan Semen Portland (Ilyas, Rahayu \& Arifin , 2008). Dengan kesimpulan antara lain :

1. Hasil nilai CBR maupun swelling menunjukkan semakin banyak kadar PC-V yang ditambahkan dan semakin lama masa peram maka semakin naik nilai CBR-nya, sedangkan nilai swelling semakin turun..

2. Dari hasil uji Triaxial $\mathrm{CU}$, hasil terbaik didapat Hasil penelitian menunjukkan bahwa nilai CBR, dan kepadatan standar naik dengan nai knya presentase semen didalam tanah. Pada kadar semen tersebut terlihat adanya penurunan potensi pengembangan dan peningkatan nilai CBR yang cukup signifikan. Pada pengujian tekan bebas terlihat bahwa semakin tinggi kadar semen, nilai parameter kuat geser tanah semakin naik. Penambahan semen telah mengingkatkan nilai daya dukung tanah secara singnifikan. Nilai CBR semakin naik jika seiring dengan penambahan semen, dimana nilai CBR tanah asli sebesar $1,62 \%$. Terjadinya peningkatan nilai CBR pada campuran optimum 7\% semen dengan waktu pemeraman 3 hari dengan nilai CBR 3,76\% pada masa peram 4 hari dan kadar PC-V $30 \%$. Namun untuk sudut geser dalam efektif ( $\left.\Phi^{\prime}\right)$ tidak selalu turun mengikuti penambahan kadar PC-V ataupun lamanya masa peram.

3. Hasil uji mikroskopik SEM memperlihatkan gumpalan-gumpalan flokuasi akibat reaksi semen hidrasi semakin besar dengan penambahan kadar PC-V. Partikel tanah semakin kohesif dan sesuai dengan hasil Triaksial CU dimana nilai kohesi (c') semakin besar. 
4. Dalam SEM dan uji XRD dapat dilihat bahwa gel CSH (Calsium-SilikatHidrat ) sebagai pengikat partikel tanah memegang peranan penting untuk kekuatan sampel tanah dan kadarnya meningkat dengan bertambahnya PC-V.

5. Tanah gambut Kalimantan ini merupakan tanah dengan kadar organik sangat tinggi hingga mencapai 92,33 \% dengan $\mathrm{pH}=3,30$. Uji XRD hanya menemukan mineral kuarsa ( Alpha Quartz ) dalam jumlah kecil di antara material- material amorphe. Senyawa baru yang dihasilkan akibat JURNAL TEKNOLOGI, Edisi No. 1 Tahun XXII, Maret 2008 1-8 2 Studi Perilaku Kekuatan Tanah Gambut Kalimantan yang Di-Stabilisasi dengan Semen Portland 3 JURNAL TEKNOLOGI, Edisi No. 1 Tahun XXII, Maret 2008, 1-8 reaksi semen hanyalah portlandite $\mathrm{Ca}(\mathrm{OH}) 2$ dan gel $\mathrm{CSH}$. Berbeda dengan penelitian sebelumnya untuk gambut Sumatera dimana dinyatakan dalam kondisi murninya mempunyai mineral - mineral pembentuk lempung seperti Hydromica dan Halloysite.

6. Untuk aplikasi di lapangan, terkait dengan hasil yang didapat dari percobaan di laboratorium hanya menghasilkan nilai CBR sekitar 3\%. Nilai tersebut berdasarkan klasifikasi Cassagrande termasuk subgrade yang buruk karena nilai CBR-nya kurang dari $5 \%$ sehingga hanya dapat digunakan untuk jalan pedesaan atau perumahan dan bukan untuk jalan yang dilalui kendaraan berat.

\begin{abstract}
Analisa
Pemakaian semen sebagai bahan adiktif banyak digunakan dalam beberapa penelitian di Indonesia terutama terkait dengan peningkatan kekuatan tanahnya. Dalam tulisan ini, pemakaian bahan stabilisasi semen diamati dari efek penggunaannya, seperti rentang kadar air tanah campuran, serta dari segi ekonomisnya. Stabilitas Tanah menggunakan semen tergantung pada jenis tanah apa yang akan digunakan atau yang akan dicampurkan dengan semen. Tanah gambut dikategorikan ke dalam tanah lunak yang sering digunakan bila harus dilalui oleh suatu trase jalan. Selain itu tanah gambut memiliki tekstur terbuka di mana selain pori-pori makro, tekstur tanah gambut juga didominasi oleh pori-pori mikro yang berada di dalam serat gambut Dengan sistem pori ganda dan tingkat homogenitas yang tidak merata tersebut,serta berat isi tanah yang mendekati berat isi air, maka masalah penurunan yang besar menjadi masalah utama bagi struktur yang akan dibangun diatasnya. Salah satu cara untuk memanfaatkan tanah gambut sebagai bahan jalan adalah dengan cara stabilisasi tanah. Stabilisasi yang dimaksud sebenarnya adalah solidifikasi, yaitu penambahan zat aditif ( baik dalam bentuk sebenarnya atau hanya terkandung dari suatu bahan ) ke dalam suatu massa tanah untuk meningkatkan sifat mekanis-nya.
\end{abstract}

\title{
KESIMPULAN
}

1. Hasil menunjukan bahwa di Kabupaten Sorong nilai CBR, dan kepadatan standar naik dengan naiknya presentase semen didalam tanah. Pada kadar semen tersebut terlihat adanya penurunan potensi pengembangan dan peningkatan nilai CBR yang cukup signifikan. Pada pengujian tekan bebas terlihat bahwa semakin tinggi kadar semen, nilai parameter kuat geser tanah semakin naik. Penambahan semen telah mengingkatkan nilai daya dukung tanah secara singnifikan. Nilai CBR semakin naik jika seiring dengan penambahan semen, dimana nilai CBR tanah asli sebesar $1,62 \%$. Terjadinya peningkatan nilai CBR pada campuran optimum 7\% semen dengan waktu pemeraman 3 hari dengan nilai CBR 3,76\%, menurut ( Pristianto, 2018 ) 
2. Hasil menunjukan bahwa di Kalimantan terkait dengan hasil yang didapat dari percobaan di laboratorium hanya menghasilkan nilai CBR sekitar 3\%. Nilai tersebut berdasarkan klasifikasi Cassagrande termasuk subgrade yang buruk karena nilai CBR-nya kurang dari $5 \%$ sehingga hanya dapat digunakan untuk jalan pedesaan atau perumahan dan bukan untuk jalan yang dilalui kendaraan berat, menurut (Ilyas, Rahayu \& Arifin , 2008)

\section{DAFTAR PUSTAKA}

1. Rokhman, R., \& Pristianto, H. (2018, April 22). UJI EKSPERIMEN STABILISASI TANAH DASAR DENGAN SEMEN PADA RUAS JALAN MALAWILI DISTRIK AIMAS KABUPATEN SORONG. http://doi.org/10.17605/OSF.IO/KNZGE

2. Ilyas, T., Rahayu, W., \& Arifin, D. S. (2008). Studi Perilaku Kekuatan Tanah Gambut Kalimantan yang distabilisasi dengan Semen Portland. Jurnal Teknologi, 21, 1-8.

3. Pristianto, H., Amri, I., \& Rusdi, A. (2014, May 9). Pedoman Penulisan Tugas Akhir Fakultas Teknik Universitas Muhammadiyah Sorong 2014. http://doi.org/10.17605/OSF.IO/4VTJM. 